\title{
Developing Mathematical Problem-Based Learning Devices on Social Aritmetic Topic to Improve Creative Thinking Skills of Junior High Schools Students
}

\author{
Endar Chrisdiyanto, Zudhy Nur Alfian, Aji Pangestu \\ Mathematic Education Department, Faculty of Mathematic and Natural Science, Yogyakarta State University \\ Jl. Colombo No. 1, Karangmalang, Caturtunggal, Depok, Sleman, D.I. Yogyakarta
}

\begin{abstract}
The objective of this development research is to produce a mathematical problem-based learning tool on the topic of social arithmetic to improve the creative thinking skills of junior high school students. This research describes the quality of the learning tools developed in terms of three aspects, namely validity, practicality, and effectiveness. The development model employed in the development of this learning device is the ADDIE model. The ADDIE model consists of analysis, design, development, implementation, and evaluation. Learning devices meet the validity criteria indicated by the lesson plan score of 151 in the very good category. The assessment score of student's worksheet is 125 which is in a very good category. Teacher questionnaire responses obtain a score of 87 which is in the very practical category and the student response questionnaire obtains a score of 68.29 which is in the very practical category. The results of the analysis on the effectiveness show that the learning device meets the effectiveness criteria viewed from the percentage of completeness of $87 \%$, the significance value of $0,000<\alpha(0.005)$, and the value of $t$ count $(6,604)>t$ table $(1,645)$.
\end{abstract}

Keywords: creative thinking, learning devices, problem-based learning.

\section{INTRODUCTION}

Learning tools are a set of tools that will be used to support the implementation of the learning process and to achieve learning objectives. Based on Permendikbud Number 22 Year 2016 it is explained that learning tools include syllabus, lesson plans (RPP), student worksheets (LKS), media, learning resources, assessment tools, and learning activity scenario. These learning tools must be arranged in accordance with the standards of the learning process. Curriculum changes cause changes to the 4 basic parts of the 2013 curriculum which are based on BSNP covering process standards, assessment standards, content standards, and graduation standards. Changes to these 4 sections require teachers to be innovative and creative during learning activities. In an effort to create learning according to the educational process standards, it can be done by developing learning tools. Learning tools that can be developed are RPP and LKS. This is in accordance with Permendikbud No. 22 of 2016 concerning process standards explained that every educator is required to compile lesson plans in a complete and systematic manner so that learning is fun, challenging, efficient, and motivates students to participate actively during learning activities carried out.

This contradicts research conducted by Sulistyani \& Retnawati (2015: 199) that most of the learning tools used by teachers are obtained from the internet and the lesson plans used are lesson plans from the previous year which do not change each year. Rusgianto (2014) states that there are only a few teachers who develop learning tools. In addition to preparing lesson plans teachers must also compile worksheets. Based on the Ministry of National Education (2008: 42-45) explained that the purpose of using LKS is to help in finding and understanding a concept in solving problems.

The fact shows that many teachers still use lecture and expository methods which cause students to be passive in the process of learning mathematics. Changes in the 2013 curriculum led to changes in the learning process from teacher-centered to student-centered. This change in learning process causes students to be active in learning activities, including in learning mathematics. Based on Permendikbud (2013: 7) explained that the purpose of the 2013 curriculum is to prepare someone to have the ability to live as a person and a citizen who is faithful, productive, creative, innovative, and affective. Efforts that can be made by teachers are preparing learning tools that are suitable to the needs and characteristics of students. Thus the teacher must develop learning devices that are appropriate to the characteristics of students, increase student activity, and enhance students' creative thinking abilities.

The learning approach that facilitates students to be active in learning activities is problem based learning. Problem based learning is a teaching method that requires students to actively collect and apply knowledge to solve problems (Miao, 2000: 232). According to Arends (2012: 396) that the problem based learning model provides meaningful problems for students to encourage students to find solutions to solving those problems. 
According to Herman (2007) states that the characteristics of problem based learning are placing students as self-directed problem solvers, encouraging students to find problems and planning solutions, facilitating students to explore various alternative solutions, training students to skillfully present findings, and accustoming students to reflect on the effectiveness of their way of thinking.

The problem based learning approach trains students in developing creative thinking skills. Siswono (2009) states that there is a link between problem solving and the ability to think creatively because creative thinking is a process used to come up with ideas and combine them to find solutions to existing problems.

Based on the Ministry of Education and Culture (2013: 267) states that creative thinking is one of the standard objectives of the content of mathematics subjects in SMP / MTs which is summarized in the formation of creative thinking abilities and curiosity. This is reinforced by Siswono (2009) who explains that one of the goals of mathematics learning is developing creative activities that involve imagination, intuition and discovery. From this opinion shows that the importance of increasing the ability to think creatively in mathematics learning activities.

Based on the results of interviews with teachers in SMP N 1gantiwarno, the implementation of learning in schools lacks in facilitating students in creative thinking. In addition, the teacher stated that students were less active in learning activities. Most students wait for the teacher to explain or wait for their friends to work in front of the class. This shows that the ability of students in creative thinking is still low as seen from their ability to solve problems

Routine and non routine. In addition, the mathematics teacher stated that he had not yet developed a problembased worksheet. This can be seen from the worksheet used by students obtained from printing and not in accordance with the conditions and characteristics of students.

Based on the description above, the importance of developing mathematical problem-based learning tools on social arithmetic topics to improve the creative thinking ability of junior high school students.

\section{MATERIAL AND METHODS}

\section{Study Area}

This study use research and development methode with ADDIE (Analysis, Design, Development, Implementation, and Evaluation) model. The study held since February $12^{\text {nd }}$ until March $13^{\text {rd }}$ in 2019 and held on SMP N 1 Gantiwarno Klaten.

\section{Procedures}

The development model used in this study is the ADDIE model. ADDIE model consists of analysis, design, development, implementation, and evaluation (Benny, 2009: 128-132). At this stage of analysis it is carried out with needs analysis, student analysis, curriculum analysis, and situation analysis. At the design stage, this is done by developing learning tools in the form of lesson plans and worksheets in accordance with the ability to be improved, namely the ability to think creatively. At the development stage, the instrument validity is carried out by experts. The implementation phase is carried out by testing developed products that have been validated by experts and revised. This evaluation phase is carried out by evaluating the results of the device trials conducted.

\section{Instruments, and Data Collection Techniques}

The tools developed in this study consisted of lesson plans, student worksheets, and creative thinking skills test questions. Data collection techniques are done by tests and non-tests. Data collection by tests is used to measure creative thinking skills. The results of tests carried out to measure aspects of effectiveness. Whereas non-test data collection techniques were carried out with an observation sheet the implementation of learning activities and student response questionnaire and teacher response questionnaire.

There are several instruments used in the assessment of research, namely the learning device assessment sheet that was developed, the observation sheet of the implementation of learning, the student response questionnaire sheet, the teacher's response questionnaire sheet, and the ability to think test. The instruments in this data collection were divided into 3 criteria namely validity, practicality, and effectiveness instruments. Validity instruments include RPP validation, worksheet validation, student response questionnaire validation, teacher response questionnaire validation, and creative thinking skills test question validation. Practical assessment instruments include teacher response questionnaires, student response questionnaires, and observations of learning outcomes. While the effectiveness instruments include tests of creative thinking skills.

The results of expert validation are used to determine the validity level of the instruments developed and will be improved based on suggestions and input from the validator. The results of the tests of creative thinking skills are used to measure the effectiveness aspects of the use of learning tools that are developed and the thinking abilities that you want to measure.

The test questions of creative thinking skills consist of 5 problem descriptions. Test scores are converted so that they range from 0 to 100 . These grades are then classified into categories. The effectiveness value for the 
ability to think creatively is the average value of at least reaching the good category $(60<x>80)$.

\section{Data Analysis}

Analysis techniques are carried out to obtain learning tools that meet the valid, practical, and effective aspects. Validity Data Analysis

This validity analysis was carried out on the developed learning tools, namely the lesson plan (RPP) and Student Activity Sheet (LKS)

Table 1. Validity Category of Lesson Plan and Students Worksheet.

\begin{tabular}{ccr}
\hline \multicolumn{2}{c}{ Interval } & Description \\
\hline RPP & LKS & \\
\hline$X>142,806$ & $X>121,812$ & Very Good \\
$115,602<X \leq 142,806$ & $98,604<X \leq 121,794$ & Good \\
$88,398<X \leq 115,602$ & $75,396<X \leq 98,604$ & Pretty Good \\
$61,194<X \leq 88,398$ & $52,188<X \leq 75,396$ & Poorly \\
$X \leq 61,194$ & $X \leq 52,188$ & Not Good \\
\hline
\end{tabular}

\section{Practicality Analysis Data}

This practicality analysis is used to find out how the level of implementation of the learning process is done by teacher questionnaire responses and student response questionnaires.

Table 2. Teacher Questionnaire Responses.

\begin{tabular}{ccc}
\hline & Interval & Criteria \\
\hline & $X>70,2$ & Very Good \\
Lesson Plan and & $59,4<X \leq 70,2$ & Good \\
Student & $48,6<X \leq 59,4$ & Pretty Good \\
Worksheet & $37,8<X \leq 48,6$ & Poorly \\
& $X \leq 37,8$ & Not Good \\
\hline
\end{tabular}

Table 3. Student Response Questionnaires.

\begin{tabular}{cc}
\hline Interval & Criteria \\
\hline$X>62,4$ & Very Good \\
$52,8<X \leq 62,4$ & Good \\
$43,2<X \leq 52,8$ & Pretty Good \\
$33,6<X \leq 43,2$ & Poorly \\
$X \leq 33,6$ & Not Good \\
\hline
\end{tabular}

Products that are developed meet practical criteria if they meet the minimum good category and practical criteria if $80 \%$ of students meet the good criteria.

The observational observance analysis was carried out to determine the suitability of the learning tools developed and to support the level of practicality and effectiveness. The results of literacy found that the average implementation of learning obtained an average of $99 \%$ and in the very good category.

\section{Analysis of Effectiveness Data}

Analysis of the results of the effectiveness of the test data developed by 10 multiple choice questions and 4 essay questions. Multiple choice questions to find out the level of achievement of competence. While the problem description is used to measure the ability to think creatively with an ideal minimum score of 0 and an ideal maximum score of 100.

Table 4. Creative Thinking Response Category.

\begin{tabular}{cc}
\hline Interval & Category \\
\hline$X>80$ & Very Good \\
$60<X \leq 80$ & Good \\
$40<X \leq 60$ & Pretty Good \\
$20<X \leq 40$ & Poorly \\
$X \leq 20$ & Not Good \\
\hline
\end{tabular}

Learning tools are said to be effective if the percentage of the number of students who get KKM scores is more than $75 \%$ and the average student test score is more than 69.99 .

Problem based learning in terms of students' creative thinking ability is said to be effective if it meets two criteria. The first criterion is if the average value of students' creative thinking abilities is more than 69.99. The test used is the One-Sample T-Test with a significance level of 0.05 . The second criterion is if the number of students who achieve the test score of creative thinking ability is at least more than $75 \%$, with a significance level of 0.05 .

\section{RESULT AND DISCUSSION}

\section{Result}

Mathematical learning tools were developed to find out three aspects to be measured namely validity, practicality, and effectiveness. This tool was developed with the ADDIE model which consists of five stages, namely analysis, design, development, implementation, and evaluation. Explanation of the stages of development is as follows.

\section{- Analysis}

a) Requirements Analysis

The results of the needs analysis found that the ability of students to think creatively is still low as seen from the way students answer the questions when the teacher gives practice questions.

b) Student Analysis

Based on observations made indicate that students are less active in learning activities as seen from students who are afraid to ask if they have difficulty or do not understand the material being taught.

c) Curriculum Analysis

This curriculum analysis is used to find out the subject matter that will be used in research. Based on observations made with teachers, information was obtained that SMP Negeri 1 gantiwarno used the 2013 revised 2016 curriculum.

d) Situation Analysis

Based on observations at SMP Negeri 1 Bukawarno, it was shown that SMP Negeri 1 Bukawarno supported the research site. 


\section{- Design}

The design in the study was carried out by compiling the developed learning tools namely RPP and LKS and the preparation of quality assessment instruments from the developed tools. Learning tools are arranged by the teacher so that the learning and evaluation process can be arranged systematically (Nazarudin, 2007: 113).

\section{- Development}

The learning device that has been compiled is validated by the lecturer to determine the validity of the learning device developed. At this stage the development of lesson plans, worksheets, and test instruments for creative thinking skills is carried out.

Validity Analysis

Validity analysis is carried out on the learning tools developed. This learning tool is validated by the validator. The results of the validation are as follows.

Validity of the developed lesson plan

The validity of the lesson plan is determined from the results of the validation conducted by two validators. The results of the validity assessment of the first validator are 158 and the second validator is 144 . The results of the validity assessment carried out indicate that the average validity of the developed learning kit is 151 with very good criteria and deserves to be tested.

\section{- Implementation}

This research was conducted in SMP Negeri 1 gantiwarno class VII E. The number of students in class VII E amounted to 31 students. This research was conducted on 10 February 2019 - 13 March 2019. The study was conducted in 7 meetings.

\section{- Evaluation}

Evaluation is used to improve learning tools that are developed and adjusted for suggestions and input for improvement of devices. In addition, in the evaluation stage, an analysis of learning tools developed and test questions was carried out to improve the ability to think creatively.

\section{a) Practical Analysis}

Practicality assessment is based on student response questionnaire and teacher response questionnaire. The practical analysis results of the learning tools developed as follows.

- Teacher Response Questionnaire

There are three aspects that are assessed namely material aspects, lesson plans and worksheets. The following analysis results from the teacher's questionnaire responses as follows.

Table 5. Teacher's Questionnaire Responses.

\begin{tabular}{lll}
\hline Aspect & Mean & Criteria \\
\hline Material & 5 & Very Good \\
Lesson Plan & 4,89 & Very Good \\
Worksheet & 4,78 & Very Good \\
\hline Conclusion & 4,83 & Very Good \\
\hline
\end{tabular}

Based on the results above shows that the average value obtained is 4.83 and is included in the criteria very well.

- Student Response Questionnaire

Questionnaire responses of these students to measure the level of practicality of the learning device developed. The following results of the analysis of the questionnaire responses of students as follows.

The results of the validator's assessment showed that the average value of the student response questionnaire was 68.29 and included in the very good criteria.

- Implementation Observation Sheet

The results of the analysis of the observation sheet of the implementation of learning above shows that the average implementation of learning is $99 \%$. These results indicate that learning activities are going well.

\section{b) Effectiveness Analysis}

Analysis of the effectiveness of learning tools is obtained from the results of competency achievement tests and tests of creative thinking abilities conducted. The following analysis of the results of tests conducted and analysis of creative thinking skills conducted.

Table 6. Result of tests.

\begin{tabular}{|c|c|}
\hline Aspect & Result \\
\hline Students complete & 31 \\
\hline Students not complete & 4 \\
\hline Maximal score & 100 \\
\hline Minimal score & 60 \\
\hline Average & 80,806 \\
\hline Complete percentage & $87 \%$ \\
\hline Conclusion & Very Good \\
\hline
\end{tabular}

Learning activity is effective if the percentage of completeness is more than $75 \%$ and the average obtained is more than 69.99. The analysis shows that students meet the effectiveness criteria as seen from the number of students who reach the KKM of more than $75 \%$. The achievement test results obtained an average percentage of each aspect of $86.45 \%$ and in the very good category. While the results for the ability to think creatively indicate that the average overall complication of each aspect is 3.28 with a percentage of $82 \%$ and the criteria are very good. The effectiveness test of the learning tool developed as follows.

- Normality Test

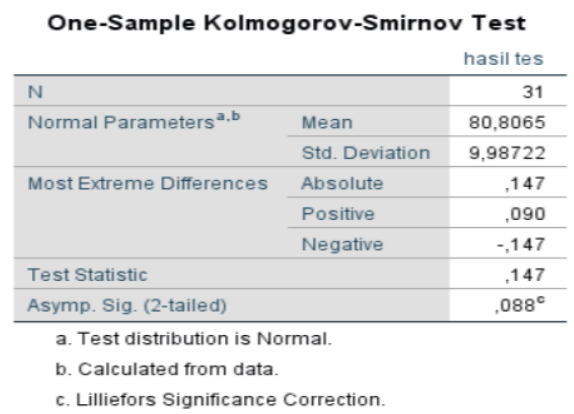

Figure 1. Normality Test Result 
Based on the table above shows that the results of students' creative thinking tests obtained significance values. This value indicates that the data used are normally distributed.

- Test the effectiveness of the developed learning device hypothesis

\begin{tabular}{l|l|l|r|r}
\multicolumn{3}{c}{ One-Sample Statistics } \\
& & & & \\
& $N$ & Mean & Std. Deviation & $\begin{array}{c}\text { Std. Error } \\
\text { Mean }\end{array}$ \\
\hline hasil tes & 31 & 80,8065 & 9,98722 & 1,79376 \\
\hline
\end{tabular}

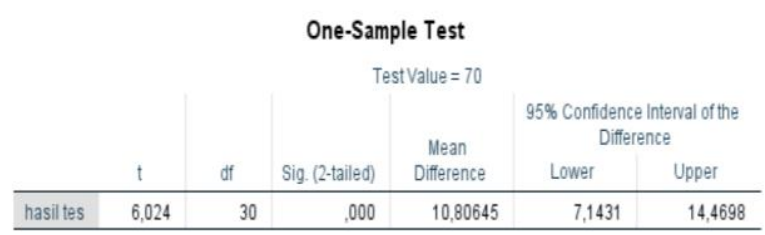

Figure 2. One sample t-test result.

Based on the above table, the significance value obtained is rejected. These results indicate that the average value of the ability to think creatively more than 69.99. Then the value of $t(6.024)>t$ table (1.645). Therefore, it can be concluded that mathematical problem-based learning tools on the topic of social arithmetic are effectively seen from the ability to think creatively.

\section{Disscussion}

This study aims to produce mathematical problem-based learning tools on the topic of social arithmetic to improve the creative thinking skills of junior high school students. The development model carried out in the research is ADDIE. The analysis conducted is the needs analysis, curriculum analysis, student analysis and situation analysis.

At the design stage, design is done by designing learning tools in the form of lesson plans and worksheets based on problems prepared based on the Minister of Education and Culture Regulation No. 24 of 2016. The stages of activities in the lesson plans are adjusted to the PBL approach consisting of analyzing problems, planning problem solving, investigating problems, presenting problems the results of discussions, and analyze and evaluate learning activities.

At the development stage (development) is carried out the preparation of lesson plans and worksheets. The preparation of the RPP is based on the design results and adjusted to Number 22 of 2016 concerning process standards. Whereas the worksheet is developed by taking into account several aspects namely didactic, construction, technical, material, and suitability of the worksheet. At the development stage, validity analysis of the learning tools developed was carried out. RPP validation results obtained an average score of 151 with an average score of 4.44 and included in the criteria very well. Development of worksheets refers to the conditions of development of worksheets according to Darmodjo \& Kaligis (1992: 41-45), namely didactic, construction, and technical requirements. LKS validation results show an average number of scores of 125 and an average score of 4.31 included in the criteria very well.

At the implementation stage it was carried out at SMP Negeri 1 Gantiwarno especially in class VII E with a total of 31 students. The device test was conducted in four meetings and one meeting to test the ability to think creatively. The learning tools developed received very positive responses. This is seen from the results of the teacher's response questionnaire, student response questionnaire, and test results.

In the evaluation phase (evaluation) is done by analysis and improvement of the learning tools that have been tested. The results of data analysis are used to find out how the feasibility of the learning kit is seen from three aspects of assessment according to Nieveen (1991), namely validity, practicality, and effectiveness. The results of the analysis of learning tools and the description of each of the results of the analysis are carried out as follows.

Practicality data analysis was carried out by giving questionnaires to teacher responses, questionnaires for student responses and sheets for the implementation of learning. Based on the results of the teacher's questionnaire responses, values were 87 and an average of 4.83. While the results of the questionnaire analysis of student responses obtained an average value of 4.216 and included in the excellent category. In addition the results of observations of the feasibility obtained an average of $99 \%$ and in the very good category.

The effectiveness analysis is done by testing the ability to think creatively. This test is carried out at the end of the learning activity to measure the effectiveness of the learning tools developed. Test questions consist of multiple choice questions and description questions. MCQs are used to determine the level of competency achievement. Multiple choice test results obtained an average value of $86.45 \%$. While the description test questions are used to measure students' abilities in creative thinking. This test was attended by 31 students and the results showed that 27 children achieved completeness and 4 children did not achieve completeness. The percentage of completeness obtained by $87 \%$. Based on the hypothesis test carried out on the test of creative thinking ability, it was found that the significance value was rejected. This means that the average value of a student's creative thinking ability test is more than 69.99 .

\section{CONCLUSION}

The assessment score of student's worksheet is 125 which is in a very good category. Teacher questionnaire responses obtain a score of 87 which is in the very 
practical category and the student response questionnaire obtains a score of 68.29 which is in the very practical category.The results of the analysis on the effectiveness show that the learning device meets the effectiveness criteria viewed from the percentage of completeness of $87 \%$, the significance value of $0,000<\alpha(0.005)$, and the value of $t$ count $(6,604)>t$ table $(1,645)$. Based on the results of the analysis of creative thinking abilities tests, it was found that the fluency aspect reached a percentage of $75.36 \%$, the flexibility aspect reached a percentage of $75 \%$, the authenticity aspect reached a percentage of $75 \%$, and the elaboration aspect reached a percentage of $77.01 \%$. This aspect shows that students are able to solve the problem given in detail and clearly.

\section{REFERENCES}

Arends, R.I. 2008. Learning to teach. (Penerjemah: Helly Prajitno \& Sri Mulyani). New York: Mc Graw Hill Company.

Benny, A.P. 2009. Model desain sistem pembelajaran. Jakarta: Dian Rakyat.

Darmodjo, H. \& Kaligis, J. (1992). Pendidikan IPA 2. Jakarta: Depdikbud.
Evans, J.R., \& Lindsay, W.M. (2008). The management and control of quality (7th ed). Ohio: Thomson South-Western.

Herman, T. 2007. Pembelajaran berbasis masalah untuk meningkatkan kemampuan berpikir kritis matematis tingkat tinggi siswa Sekolah Menengah Pertama. Jurnal Education, $1,1,2007$.

Mendikbud. 2016. Permendikbud No. 22 Tahun 2016, tentang Standar Proses Pendidikan Dasar dan Menengah

Miao, Y., Holst, S.J., Haake, J.M., et al. (2000). PBL-protocols: Guiding and controlling problem based learning process in virtual learning environment. GMD: Darmstad.

Nieveen, N.E. (1999). Design approaches and tools in education and training.

Dordrecht: Kluwer Academic Publishers.

Rusgiyanto, H.S., \& Suhartini. (2014). Pengembangan perangkat pembelajaran matematika untuk siswa SMK jurusan akuntansi di Sleman dengan pendekatan pembelajaran kontekstual. Jurnal Riset Pendidikan Matematika, 69-76.

Siswono, T.Y.E. (2009). Konstruksi teoritik tentang tingkat berpikir kreatif siswa dalam matematika. Surabaya: Jurusan Matematika FMIPA UNESA.

Sulistyani, N \& Retnawati, H. (2015). Pengembangan perangkat pembelajaran bangun ruang di SMP dengan pendekatan problem-based learning. Jurnal Riset Pendidikan Matematika,197-210. 